УДК 821. 161.2 - 94.09 "18"(043)

Пустовім В. Ю.

доктор філологічних наук, професор кафедри української мови та літератури Східноукраїнського національного університету імені Володимира Даля

\title{
«МОЯ ЛІТЕРАТУРА - В МОЇХ ЛИСТАХ» \\ (літературно-культурний дискурс епістолярію Василя Стефаника)
}

У статті розглядаються листи письменника крізь призму його життєпису й творчості. Доведено, щьо епістолярна спадщина є ключем до творчої лабораторії новеліста, виокремлено жанрово-тематичні особливості листів.

Ключові слова: лист, епістола, література.

В статье рассматриваются письма писателя сквозь призму его жизнедеятельности и творчества. Доказано, что эпистолярное наследие является ключом к творче ской лаборатории новелиста, определено жанрово-тематические особенности писем.

Ключевье слова: письмо, эпистола, литература.

The writer's letters are considered in the article through the prism of his life writing and art works. It was proved that epistolary heritage is the key to the written laboratory of the novelist; genre and topical peculiarities of the letters are separated.

Key words: letter, epistle, literature.

Сучасний розвиток суспільства вимагає від людства освоєння новітніх технологій, молодь не уявляє себе без гаджетів, інтернету та віртуального життя. На жаль, листовне спілкування вже є ознакою минувшини, бо на зміну прийшли електронні засоби, які не зберігаються в людській пам’ятті. 3 огляду на це, епістолярна спадщина минулого цінна для нащадків своєю автентичністю, а письменницьке листування - це першоджерело для осмислення його світогляду, індивідуального стилю, творчої особистості. 
Нам багато відомо про творчість одного 3 найкращих новелістів кінця XIX - поч. XX ст. Василя Стефаника. Зауважимо, що майбутній письменник народився в знаменний для української літератури рік - 1871, саме тоді прийшли у світ таланти першорядної ваги: Леся Українка, Микола Вороний, Лесь Мартович та ін. У радянських підручниках ніколи, або заідеологізовано подавалася біографія В. Стефаника, причому навмисно замовчувалися деякі аспекти. Мабуть тому сьогодні українська біографістика поповнилася новими творами про письменника, зокрема психобіографія Степана Процюка «Троянда ритуального болю» та книга Романа Горака «Кров на чорній ріллі» $\epsilon$ безперечно новим словом у стефаникознавстві. Започатковано серії книг «Життя видатних дітей», де подано цікаві історії 3 дитинства майбутніх письменників, про Василя Стефаника оповідає Степан Процюк.

У науковому дискурсі епістолярій письменника також перебував у полі зору дослідників. Одним із перших до аналізу звернувся В. Гладкий у розвідці «Епістолярна спадщина i новели Василя Стефаника» (1967). Ïї метою було вивчення листів новеліста в історико-літературному, суспільно-теоретичному та літературно-естетичному аспектах. Новизна дослідження полягала в аналізі листів прозаїка в контексті художньої творчості письменника. Тема Кракова в житті й творчості В. Стефаника неодноразово піднімалася Ф. Погребенником, В. Полєком. Є. Баран вивчав художньо-естетичні погляди, образ жінки, Б. Кир'ячук досліджував герменевтичну природу епістолярію, Р. Піхманець аналізує творчі контакти, М. Марусяк досліджує епістолярій як один із аспектів вивчення життєпису 3 урахуванням суспільно-політичної і культурної обстановки тієї доби, В. Грещук підготував аналітичне дослідження про здобутки лінгвістичного стефаникознавства.

Епістолярна спадщина Василя Стефаника окреслена 1888-1935 роками i налічує сьогодні понад триста листів, уміщених у третьому томі повного зібрання творів письменника 1954 року, решта - представлена в різних періодичних виданнях, збірниках, наукових розвідках, присвячених його творчості. 
Серед дописувачів Стефаника відомі особистості того часу, які постійно спілкувалися з новелістом: родина Морачевських, О. Кобилянська, О. Гаморак, Б. Грінченко, М. Шухевич, М. Павлик та ін.

Михайлина Коцюбинська наголошувала про унікальність Стефаникової епістоляріїі, що полягає в особливостях «Стефаникового типу листування творення себе в листах» [Коцюбинська 2001: 172].

Перший лист письменника датовано 1895 роком до В. Морачевського, написаний у в'язниці під впливом «тюремних» вражень. Лист має автобіографічну згадку про гімназійне приниження, яке супроводжувало Стефаника все життя. Уже будучи п'ятдесятирічним чоловіком при згадці про гімназію він прокидався в холодному поту.

На противагу цим сумним і болючим спогадам приходить світлий образ матері, яка прищепила любов і співчуття до людської долі: «Донині у мене іншої любові нема, як до матері, і я тяжко терпів» [Стефаник 1979: 305]. Духовний зв’язок з мамою був надзвичайно міцним і до останнього мама завжди була в серці письменника.

Працюючи у переломні для України часи, коли вся відповідальність лежала на інтелігенції, Стефаника страшно обурювала іiі бездіяльність, псевдопатріотизм. У листах він доволі різко висловлювався: «Я перестав любити руську інтелігенцію» [Стефаник 1979: 304], «... світогляд же тодішньої і теперішньої інтелігенції руської лишився один - нереальний $i$ безлично дурний» [Стефаник 1979: 306], «Для неї, інтелігенції, я не маю серия. Писати для неї не буду. Не можна любити то, що вродилося тому п'ятдесят років і є маленьке та до того миршаве. Оправдати я годен, але любити не можу» [Стефаник 1979: 326-327].

У листах Стефаника наскрізною темою проходить просвітницька діяльність через художню творчість та ідея служіння рідному народу. Його талант був визнаний не лише Україною, а й найкращими світовими письменниками, однак до себе й своєї творчості він ставився самокритично: «Я готовий пристати на те, що мої оповідання закороткі, за борзо шкіиєковані, 
загрубі, аби увійшли в літературний журнал. Будовою своєю вони, мої оповідання, не кривдять естетики і штуки» [Стефаник 1979: 322].

Літературну працю новеліст уважав збитковою у матеріальному плані, але значущою в духовному, однак не придатною до «мужицького сприймання», як-от: «Я щуе маю наших літераторів за дуже нещзасливих людей. Вони говорять до свої публіки, вона нічо, вони пафосом намагають, $i$ вона знов нічо!» [Стефаник 1979: 323]. Саме задля мужицького світорозуміння i присвячував свої писання Стефаник: «Я люблю мужиків за їх тисячолітню, тяжку історію, за культуру, щуо витворила з них людей, котрі смерті не бояться. За них я буду писати і для них» [Стефаник 1979: 327]. Письменник у листі до О. Маковея наголошував, що писати треба голу правду мужицьку, без прикрас, а свої образки створює задля естетичного вдоволення читачів будьякого соціального рівня.

У листах до О. Кобилянської письменник радився щодо творчих планів, розповідав про враження, побачене на Краківському вокзалі, коли українці від’їжджали за кращим життям до Америки. Згодом це виллється у новелі «Камінний хрест». Історія про трагедію, що сталася у Трійці, коли батько від розпачу й голоду втопив найменшу доньку знайшла художнє втілення в новелі «Новина».

У червні 1900 р. письменник відвідав м. Чортовець на Тернопільщині, садибу однодумця Плешкана, де готував до видання дві збірки «Дорога. Новели» $\mathrm{i}$ «оезії в прозі». Проте через важку хворобу на неврастенію дописи письменника так i не були опубліковані. Листи цього періоду перейняті передчуттям смерті. 1902 р. помирає Плешкан, смертельно захворіла сестра Параска. Певні зміни внесла поїздка до Полтави (1903р.) на відкриття пам'ятника I. Котляревському, де він знайомиться 3 М. Коцюбинським, М. Старицьким, Б. Грінченком, Г. Хоткевичем, М. Вороним, Оленою Пчілкою. Звідти вирушає до Києва для закріплення дружніх письменницьких взаємин, звідти - їде до Т. Шевченка в Канів. Про все це повідомляє в листі до О. Гаморак, майбутньої дружини, зауважуючи «Я здоровий» [Стефаник 
1979: 337]. Однак, із цього часу Стефаник замовкає, двадцятирічна перерва наявна і в епістолярному спілкуванні 1903-1923 рр. Щасливе сімейне життя, висока культура дружини, народження трьох синів, однак до творчості не повернувся, щоправда, 1905 р. видав 4 збірку новел «Моє слово».

Листи після вимушеної мовчанки значно відрізняються стилем викладу. Це думки розміркованої людини, яка зазнала життєвих втрат, лише ставлення до творчості залишилося незмінним: «B мойй письменницькій діяльності $я$, оскільки міг, старався тканину найделікатнішу, яка є на світі, робітничої душі розпростерти перед людськими очима, так, щоби вона блистіла, як чисте небо, і щоби блискавки гніву ударяли громом із тої робітничої душі» [Стефаник 1979: 339].

Відомі зразки епістолярію В. Стефаника розкривають людські якості митця, творчі плани щодо написання деяких творів. Частина листів містить пейзажні та психологічні замальовки, які наближені до поезії у прозі, чимало місця відведено політичним розмірковуванням (особливо непокоївся письменник майбутнім України). Мовностилістичний аналіз дописів письменника засвідчує, що митець писав народною мовою, тим діалектом, яким спілкуються прості люди Галичини; він показав багатство та різні відтінки української мови. Це дозволяе зробити висновок: більшість листів В. Стефаника розкривають органічний зв'язок 3 художньою творчістю й подають неординарну особистість літератора.

\section{БІБЛІОГРАФІЯ}

Коцюбинська 2001 - Коцюбинська М. Моя література в моїх листах // Коцюбинська М. «Зафіксоване й нетлінне»: роздуми про епістолярну творчість. К. : Дух і Літера. Харківська правозахисна група, 2001. - С. 165-173.

Стефаник 1979 - Стефаник В.С. Вибране / Упоряд., підгот. текстів, приміт. і словник В. М. Лесина та Ф. П. Погребенника. - Ужгород: Карпати, 1979. -392 c. 